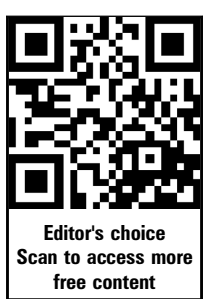
University of Florida,

Gainesville, Florida, USA

${ }^{2}$ Cerebrovascular Center,

Department of Neurosurgery,

Stony Brook University Medical

Center, Stony Brook, NY, USA

${ }^{3}$ Department of Radiology,

Medical University of South

Carolina, Charleston, South

Carolina, USA

${ }^{4}$ Cerebrovascular Program, Vanderbilt University, Nashville,

Tennessee, USA

${ }^{5}$ Department of Neurosurgery,

New York, New York, USA

\section{Correspondence to}

Dr Kyle M Fargen, Department of Neurosurgery, University of Florida, Box 100265 , Gainesville, FL 32610, USA; kyle.fargen@neurosurgery.ufl. edu

Received 5 November 2014 Accepted 9 November 2014 Published Online First 28 November 2014

\title{
A meta-analysis of prospective randomized controlled trials evaluating endovascular therapies for acute ischemic stroke
}

ABSTRACT

Introduction A recent randomized controlled trial (RCT), the Multicenter Randomized CLinical trial of Endovascular treatment for Acute ischemic stroke in the Netherlands (MR CLEAN), demonstrated better outcomes with endovascular treatment compared with medical therapy for acute ischemic stroke (AIS). However, previous trials have provided mixed results regarding the efficacy of endovascular treatment for AIS. A meta-analysis of all available trial data was performed to summarize the available evidence.

Methods A literature search was performed to identify all prospective RCTs comparing endovascular therapies with medical management for AIS. Two datasets were created: (1) all patients randomized after confirmation of large vessel occlusion (LVO) (consistent with the contemporary standard of practice at the majority of centers); and (2) all patients with outcome data who underwent randomization regardless of qualifying vascular imaging. The pre-specified primary outcome measure was modified Rankin Scale score of $0-2$ at 90 days. A fixed-effect model was used to determine significance.

Results Five prospective RCTs comparing endovascular therapies with medical management were included in dataset 1 (1183 patients) and six were included in dataset 2 (1903 total patients). Endovascular therapies were associated with significantly improved outcomes compared with medical management (OR 1.67, 95\% Cl 1.29 to 1.16, $p=0.0001$ ) for patients with LVO (dataset 1). This benefit persisted when patients from all six RCTs were included, even in the absence of confirmation of LVO (OR 1.27, 95\% Cl 1.05 to 1.54, $p=0.019$; dataset 2).

Conclusions A meta-analysis of prospective RCTs comparing endovascular therapies with medical management demonstrates superior outcomes in patients randomized to endovascular therapy.

\section{INTRODUCTION}

Although the benefits of intravenous (IV) tissue plasminogen activator (tPA) have been known for nearly 20 years, ${ }^{1}$ there remains considerable debate regarding the benefits of endovascular therapies for acute ischemic stroke (AIS) secondary to large vessel occlusions (LVO). In early 2013, three prospective randomized controlled trials (RCTs) were published demonstrating no benefit for endovascular therapies over medical management alone with regard to primary outcomes. These included the Interventional Management of Stroke (IMS III) trial $^{2}$ the Mechanical Retrieval and Recanalization of Stroke Clots Using Embolectomy (MR RESCUE) trial $^{3}{ }^{3}$ and the SYNTHESIS-Expansion trial, ${ }^{4}$ which when published together in the New England Journal of Medicine prompted skepticism in the lay press and among clinicians ${ }^{5}$ regarding the benefit of endovascular therapies in AIS. These trials provided extremely valuable information which resulted in numerous commentaries emphasizing the importance for future trials to confirm LVO and to use contemporary thrombectomy devices to ensure acceptable revascularization rates. ${ }^{6} 7$

Recently, the Multicenter Randomized CLinical trial of Endovascular treatment for Acute ischemic stroke in the Netherlands (MR CLEAN), a prospective RCT of 500 patients comparing endovascular therapies with medical management for patients with LVO, presented their results at the 9th World Stroke Congress (Istanbul, Turkey, 2014). ${ }^{8}$ Unlike the previous trials, within MR CLEAN, LVO was confirmed prior to randomization and modern devices were used to achieve acceptable revascularization rates. Primary and secondary outcomes demonstrated a significant benefit for endovascular therapies over medical therapy across all age strata.

These data have prompted a reanalysis of the available evidence for endovascular therapy in AIS. To contribute to this analysis, we conducted a meta-analysis of the existing six prospective RCTs comparing endovascular therapies with best medical management.

\section{METHODS}

\section{Eligibility criteria}

Prospective RCTs published in English comparing endovascular therapies with medical management in AIS were included. Non-randomized prospective studies, those comparing endovascular therapies with historical controls, and retrospective series were excluded.

\section{Search methods for identification of trials}

PubMed, Cochrane Central Register of Controlled Trials, and National Institutes of Health Clinicaltrials. gov were searched for studies published or presented on or before 4 November 2014. Queried subject headings included 'acute ischemic stroke', 'intraarterial', 'mechanical thrombectomy', 'randomized controlled trial', 'prospective', or similar headings. In addition, MR CLEAN presented results were included as this study is pending publication. 


\section{Data extraction}

Data were extracted from included studies by the authors in an unblinded fashion. Primary manuscripts as well as published supplementary materials or post hoc analyses were used for data acquisition. In the case of MR CLEAN, data presented at the 9th World Stroke Congress were used. ${ }^{8}$ These data were subsequently confirmed by review of the published press release in Medscape ('MR CLEAN' Polishes Stroke Outcome With Endovascular Therapy, Daniel M Keller, 29 October 2014). In trials where outcomes were only reported as the percentage of the total number of patients (and not number of subjects), the number of subjects within each stratum were extrapolated based on the total number of patients and the listed percentage for each stratum.

Study data were dichotomized into two separate datasets at the outset: (1) all available outcome data from prospective RCTs for all patients who underwent vascular imaging demonstrating LVO; and (2) all available outcome data from prospective RCTs for all randomized patients, regardless of the use of vascular imaging to identify LVO. The first dataset was therefore smaller due to the exclusion of all patients from one study $\left(\right.$ SYNTHESIS $\left.^{4}\right)$ and a subset of patients from another (IMS III ${ }^{2}$ ).

\section{Outcome measures}

Outcome measures were identical for both datasets and were analyzed separately in each dataset. The primary prespecified outcome measure was the proportion of patients achieving a modified Rankin Scale (mRS) score of $0-2$ at 90 days. The mRS score is a universally accepted and reported outcome measure among all major stroke trials ranging from a score of 0 (fully independent without symptoms or deficit) to 6 (death). Prespecified secondary outcome measures included: (1) mRS 0-1 at 90 days; (2) mRS 0-3 at 90 days; (3) mortality at 90 days; and (4) mRS shift analysis comparing mRS distributions by MannWhitney test. Patients were pooled based upon representation in a medical management arm (randomized with intention-to-treat without endovascular therapies) or in the endovascular arm (randomized with intention-to-treat with endovascular therapies).

\section{Statistical analysis}

Statistical analysis was performed by a biostatistician (DN). The $\mathrm{R}$ software package Metafor ${ }^{9}$ was used to create fixed-effects models for each dichotomous outcome. OR was chosen as the measure of analysis and each trial was weighted by the inverse of the variance of this measure. Cochran's Q test was used to assess possible heterogeneity among the trials. Using ANOVA, we tested whether any of the heterogeneity could be explained by study year, location, number of centers, difference in mean National Institute of Health Stroke Severity (NIHSS) scores between endovascular and medical arms, difference in mean age between endovascular and medical arms, mean time to endovascular treatment and treatment modality, but none of these was significantly associated with any outcome. To evaluate differences in the distribution of mRS scores between the groups ('shift analysis'), fixed-effect models were used to estimate the proportion of subjects with each score in each group for the six trials combined. The arcsin-transformed proportion was used as the measure of analysis and weighted the trials by the inverse of the variance in this measure. Estimated proportions were then applied to the combined sample size in each group and a Mann-Whitney test was used to compare the distributions of scores. This process was then repeated for the second database for all patients randomized regardless of whether pre-procedure vascular imaging demonstrated LVO.

\section{RESULTS}

\section{Search results and study characteristics for dataset 1}

Dataset 1 consisted of outcome data for all randomized patients where vascular imaging was used to confirm LVO. Five of the six prospective RCTs included from dataset 2 were also included

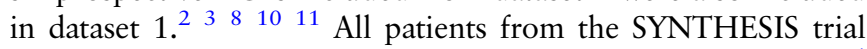
were excluded due to the absence of confirmation of LVO. ${ }^{4}$ Only the subset of patients from IMS III ${ }^{2}$ that underwent vascular imaging prior to intervention (271/629 patients with outcome data; $43 \%$ of original sample) were included in this analysis. ${ }^{12}$ Dataset 1 therefore contained a total of 1183 patients among the five trials, of which 655 (55.4\%) were randomized to endovascular therapies and $528(44.6 \%)$ were randomized to the medical arm.

\section{Search results and study characteristics for dataset 2}

Six prospective RCTs comparing endovascular therapies with medical management were identified for inclusion. ${ }^{2-481011}$ The characteristics of the six included trials are shown in table 1. A total of 1903 patients were included among the six trials, of which $1071(56.3 \%)$ were randomized to endovascular therapies and $832(43.7 \%)$ were randomized to the medical arm. Time to treatment, age, and NIHSS are shown in table 2. Table 3 lists the treatments provided in the endovascular arm and the medical arm based upon intention-to-treat. The results of primary outcome measures for the six trials are also shown in table 3.

\section{Dataset 1: comparison of endovascular and medical arms for all randomized patients with LVO confirmation}

Primary outcome measure

Table 4 shows the mRS score distributions for patients in either treatment arm in the five included trials. The pre-specified

Table 1 Characteristics of the six included studies

\begin{tabular}{|c|c|c|c|c|c|c|}
\hline \multirow[b]{2}{*}{ Trial } & \multirow[b]{2}{*}{ Trial period } & \multirow[b]{2}{*}{ Location } & \multirow[b]{2}{*}{ No of centers } & \multicolumn{3}{|l|}{ Enrollment criteria } \\
\hline & & & & Time from symptom onset & Age (years) & NIHSS \\
\hline PROACT $\|^{10}$ & 1996-1998 & North America & 54 & $<6 \mathrm{~h}$ & $18-85$ & $4-30$ \\
\hline $\mathrm{MELT}^{11}$ & $2002-2005$ & Japan & 57 & $<6 \mathrm{~h}$ & 20-75 & $5-22$ \\
\hline IMS III & 2006-2012 & North America, Europe, Australia & 58 & $<3 h$ & $18-82$ & $\geq 10(\geq 8)^{*}$ \\
\hline SYNTHESIS ${ }^{4}$ & 2008-2012 & Europe & 24 & $<4.5 \mathrm{~h}$ & $18-80$ & Any \\
\hline MR RESCUE ${ }^{3}$ & 2004-2011 & North America & 22 & $<8 \mathrm{~h}$ & $18-85$ & $6-29$ \\
\hline MR CLEAN ${ }^{8}$ & 2010-2014 & Europe & 30 & $<6 \mathrm{~h}$ & $\geq 18$ & $\geq 2$ \\
\hline
\end{tabular}

${ }^{*}$ NIHSS of 8-9 was allowed in an amendment if large vessel occlusion in internal carotid or middle cerebral artery was documented on CT angiography.

IMS, Interventional Management of Stroke; MR RESCUE, Mechanical Retrieval and Recanalization of Stroke Clots Using Embolectomy; NIHSS, National Institutes of Health Stroke Severity score. 
Table 2 Comparison of all patients enrolled in intra-arterial and medical arms of included trials

\begin{tabular}{|c|c|c|c|c|c|c|}
\hline \multirow[b]{2}{*}{ Trial } & \multicolumn{3}{|c|}{ Intra-arterial arm } & \multicolumn{3}{|l|}{ Medical arm } \\
\hline & $\begin{array}{l}\text { Mean or } \\
\text { median NIHSS }\end{array}$ & $\begin{array}{l}\text { Mean or } \\
\text { median age }\end{array}$ & $\begin{array}{l}\text { Mean time from onset to } \\
\text { intra-arterial treatment (min) }\end{array}$ & $\begin{array}{l}\text { Mean or } \\
\text { median NIHSS }\end{array}$ & $\begin{array}{l}\text { Mean or } \\
\text { median } \\
\text { age }\end{array}$ & $\begin{array}{l}\text { Mean time from onset } \\
\text { to treatment ( } \mathrm{min})\end{array}$ \\
\hline PROACT $\|^{10}$ & 17 & 64 & 308 & 17 & 64 & NR \\
\hline MELT $^{11}$ & 14 & 66.9 & 227 & 14 & 67.3 & NR \\
\hline IMS III & 17 & 69 & 249 & 16 & 68 & 121 \\
\hline SYNTHESIS ${ }^{4}$ & 13 & 66 & 225 & 13 & 67 & 165 \\
\hline MR RESCUE ${ }^{3}$ & 17.4 & 64.1 & 381 & 17.7 & 67.1 & NR \\
\hline MR CLEAN ${ }^{8}$ & 17 & 65 & 260 & 18 & 66 & $87^{*}$ \\
\hline
\end{tabular}

${ }^{*}$ For patients who received intravenous tPA.

IMS, Interventional Management of Stroke; MR RESCUE, Mechanical Retrieval and Recanalization of Stroke Clots Using Embolectomy; NIHSS, National Institutes of Health Stroke Severity score; NR, not reported; tPA, tissue plasminogen activator.

primary outcome (mRS 0-2 at 90 days) occurred significantly more frequently in patients randomized to endovascular therapies compared with medical management only $(38.3 \%$ vs $25.8 \%$, OR $1.67,95 \%$ CI 1.29 to $2.16, p=0.0001$; table 5 ; figure 1 ).

\section{Secondary outcome measures}

Table 5 shows secondary outcome comparisons. All secondary outcome measures were strongly statistically significant, except for mortality which did not differ between groups $(p=0.13)$. Outcomes of mRS $0-1$, mRS $0-3$, and mRS shift analysis were significantly better in those undergoing endovascular therapies $(\mathrm{p}<0.0001-0.002)$.

\section{Dataset 2: comparison of endovascular and medical arms for all randomized patients \\ Primary outcome measure}

Table 6 demonstrates mRS score distributions for patients in either treatment arm in the six included trials. The pre-specified primary outcome (mRS 0-2 at 90 days) occurred significantly more frequently in patients randomized to endovascular therapies compared with medical management only $(39.1 \%$ vs $32.6 \%$, OR $1.27,95 \%$ CI 1.04 to $1.54, \mathrm{p}=0.018$; table 5; figure 2 ).

\section{Secondary outcome measures}

Table 5 shows secondary outcome comparisons. The secondary outcome of mRS $0-1$ at 90 days was not significantly different in patients randomized to endovascular therapies and those randomized to medical management $(p=0.09)$. Conversely, mRS $0-3$ at 90 days occurred significantly more frequently in the endovascular arm $(p=0.019)$. Modified Rankin Score shift analysis demonstrated a significant difference between distributions, favoring endovascular therapies compared with medical management $(p=0.003)$. Mortality was not significantly different between the treatment arms $(p=0.73)$.

\section{DISCUSSION}

This meta-analysis of the six published prospective RCTs investigating and comparing the efficacy of endovascular therapies versus medical management demonstrated superior outcomes in patients randomized to endovascular therapies compared with those randomized to medical therapy. This effect was most robust in the analysis of patients with pre-procedural vascular imaging demonstrating LVO (dataset 1). In this cohort, those randomized to endovascular therapies had a 1.7 times greater odds of achieving a good outcome than those in the medical arm. The beneficial effect of endovascular therapy persisted when all randomized patients were included, regardless of preprocedural vascular imaging (dataset 2 ). In this broader analysis, the proportion of patients achieving mRS $0-2$ at 90 days was $6.5 \%$ higher in patients receiving endovascular therapy compared with medically managed patients. The beneficial effect of endovascular therapy persisted when evaluating the secondary

Table 3 Comparison of control and intra-arterial arms and study results

\begin{tabular}{|c|c|c|c|c|c|}
\hline Trial & Control arm & Intra-arterial arm & $\begin{array}{l}\text { Predominant intra-arterial } \\
\text { modality }\end{array}$ & Primary endpoint & $\begin{array}{l}\text { Primary endpoint result } \\
\text { ( } p \text { value or } 95 \% \mathrm{Cl} \text { ) }\end{array}$ \\
\hline PROACT $\|^{10}$ & IV heparin & IA prourokinase+IV heparin & IA thrombolytic & mRS $0-2$ at 90 days & IA therapy superior (0.04) \\
\hline MELT ${ }^{11}$ & Not specified & IA urokinase+IV heparin & IA thrombolytic & mRS $0-2$ at 90 days & No difference $(0.35)$ \\
\hline IMS III & IV tPA & IA thrombectomy+IV tPA & Merci Retriever & $\mathrm{mRS} 0-2$ at 90 days & $\begin{array}{l}\text { No difference }(95 \% \\
\mathrm{Cl}-6.1 \text { to } 9.1)\end{array}$ \\
\hline SYNTHESIS ${ }^{4}$ & IV tPA & $\begin{array}{l}\text { IA thrombectomy } \pm \text { IA thrombolysis+IV } \\
\text { heparin }\end{array}$ & $\begin{array}{l}\text { Wire manipulation and IA } \\
\text { thrombolytic }\end{array}$ & mRS $0-1$ at 90 days & No difference $(0.37)$ \\
\hline $\begin{array}{l}\text { MR } \\
\text { RESCUE }^{3}\end{array}$ & $\begin{array}{l}\text { IV tPA if } \\
\text { candidates }\end{array}$ & $\begin{array}{l}\text { IA thrombectomy+IV tPA if candidates } \\
+ \text { IV heparin }\end{array}$ & Merci Retriever & $\begin{array}{l}\text { mRS shift based on } \\
\text { penumbral profile }\end{array}$ & No difference $(0.99)^{*}$ \\
\hline MR CLEAN ${ }^{8}$ & $\begin{array}{l}\text { IV tPA if } \\
\text { candidates }\end{array}$ & IA thrombectomy+IV tPA if candidates & Retrievable stents & mRS shift analysis & $\begin{array}{l}\text { IA therapy superior } \\
(95 \% \mathrm{Cl} 1.21 \text { to } 2.30)\end{array}$ \\
\hline
\end{tabular}

*Comparison of endovascular versus medical arms is a secondary outcome analysis.

IA, intra-arterial; IMS, Interventional Management of Stroke; IV, intravenous; MR RESCUE, Mechanical Retrieval and Recanalization of Stroke Clots Using Embolectomy; mRS, modified Rankin Scale; tPA, tissue plasminogen activator. 
Table 4 Modified Rankin Scale (mRS) scores at 90 days for medical and intra-arterial arms of the five included trials that confirmed large vessel occlusion prior to randomization

\begin{tabular}{|c|c|c|c|c|c|c|c|c|c|}
\hline \multirow[b]{2}{*}{ Study } & \multirow[b]{2}{*}{ Arm } & \multirow[b]{2}{*}{$\mathrm{N}$} & \multicolumn{7}{|c|}{ Modified Rankin Scale score at 90 days } \\
\hline & & & $0(\%)$ & $1(\%)$ & $2(\%)$ & $3(\%)$ & $4(\%)$ & $5(\%)$ & $6(\%)$ \\
\hline PROACT $\|^{10}$ & $\begin{array}{l}\text { IA } \\
\text { Medical }\end{array}$ & $\begin{array}{r}121 \\
59\end{array}$ & $\begin{array}{l}13 \\
12\end{array}$ & $\begin{array}{r}13 \\
5\end{array}$ & $\begin{array}{r}14 \\
8\end{array}$ & $\begin{array}{l}12 \\
22\end{array}$ & $\begin{array}{l}14 \\
19\end{array}$ & $\begin{array}{l}9 \\
7\end{array}$ & $\begin{array}{l}25 \\
27\end{array}$ \\
\hline MELT $^{11}$ & $\begin{array}{l}\text { IA } \\
\text { Medical }\end{array}$ & $\begin{array}{l}57 \\
57\end{array}$ & $\begin{array}{r}16 \\
5\end{array}$ & $\begin{array}{l}26 \\
18\end{array}$ & $\begin{array}{r}7 \\
16\end{array}$ & $\begin{array}{l}11 \\
18\end{array}$ & $\begin{array}{l}19 \\
21\end{array}$ & $\begin{array}{l}16 \\
19\end{array}$ & $\begin{array}{l}5 \\
4\end{array}$ \\
\hline IMS III' ${ }^{12 *}$ & $\begin{array}{l}\text { IA } \\
\text { Medical }\end{array}$ & $\begin{array}{r}180 \\
91\end{array}$ & $\begin{array}{r}13 \\
6\end{array}$ & $\begin{array}{l}22 \\
14\end{array}$ & $\begin{array}{l}12 \\
19\end{array}$ & $\begin{array}{l}13 \\
11\end{array}$ & $\begin{array}{l}18 \\
17\end{array}$ & $\begin{array}{l}6 \\
8\end{array}$ & $\begin{array}{l}16 \\
26\end{array}$ \\
\hline MR RESCUE ${ }^{3 *} \dagger$ & $\begin{array}{l}\text { IA arms } \\
\text { Medical arms }\end{array}$ & $\begin{array}{l}64 \\
54\end{array}$ & $\begin{array}{l}3 \\
6\end{array}$ & $\begin{array}{r}11 \\
7\end{array}$ & $\begin{array}{l}5 \\
7\end{array}$ & $\begin{array}{l}16 \\
22\end{array}$ & $\begin{array}{l}23 \\
22\end{array}$ & $\begin{array}{l}23 \\
11\end{array}$ & $\begin{array}{l}19 \\
24\end{array}$ \\
\hline MR CLEAN ${ }^{8}$ & $\begin{array}{l}\text { IA } \\
\text { Medical }\end{array}$ & $\begin{array}{l}233 \\
267\end{array}$ & $\begin{array}{l}3 \\
1\end{array}$ & $\begin{array}{l}9 \\
6\end{array}$ & $\begin{array}{l}21 \\
13\end{array}$ & $\begin{array}{l}18 \\
16\end{array}$ & $\begin{array}{l}22 \\
30\end{array}$ & $\begin{array}{r}6 \\
12\end{array}$ & $\begin{array}{l}21 \\
22\end{array}$ \\
\hline TOTAL* & $\begin{array}{l}\text { IA } \\
\text { Medical }\end{array}$ & $\begin{array}{l}655 \\
528\end{array}$ & $\begin{array}{l}9 \\
4\end{array}$ & $\begin{array}{r}15 \\
9\end{array}$ & $\begin{array}{l}15 \\
13\end{array}$ & $\begin{array}{l}15 \\
17\end{array}$ & $\begin{array}{l}19 \\
25\end{array}$ & $\begin{array}{r}9 \\
11\end{array}$ & $\begin{array}{l}19 \\
22\end{array}$ \\
\hline
\end{tabular}

binary outcome of mRS $0-3$, as well as in a mRS shift analysis. These data indicate that endovascular therapies produce superior clinical outcomes compared with medical management in patients presenting with AIS from LVO.

To date, the results of prospective RCTs have been mixed. Of the six trials, only PROACT II and MR CLEAN have demonstrated a significant benefit of endovascular therapies based on their pre-specified primary outcome measures. The Japanese MELT trial was indeterminate as it was discontinued early after the approval of IV TPA in Japan. The remaining three studies (IMS III, MR RESCUE and SYNTHESIS) all demonstrated no benefit of endovascular therapies over medical management, although they also demonstrated no worsening in the endovascular arm. Important lessons were gained from these trials; in particular, it was recognized that the use of modern thrombectomy technologies was necessary, as well as the need for pretreatment vascular imaging to confirm LVO (the index disease targeted by endovascular therapies).
In the endovascular arm of MR CLEAN, 97\% of subjects were treated using retrievable stent technology (shown to be superior to older thrombectomy devices ${ }^{13}{ }^{14}$ ), yielding nearly $60 \%$ Thrombolysis In Cerebral Infarction (TICI) $2 \mathrm{~b}$ or 3 and $80 \%$ TICI $2 \mathrm{a}$ or greater revascularization. Furthermore, vascular imaging was obtained in all patients prior to randomization and IV tPA was administered to all patients who were appropriate candidates, in similar doses regardless of the treatment allocated. Even with a mean time from symptom onset to groin puncture of $>4 \mathrm{~h}$, patients randomized to endovascular therapies had a two times greater odds of a good outcome at 90 days compared with those randomized to medical management. The overwhelmingly positive results of MR CLEAN have prompted considerable discussion regarding how to appropriately interpret these data within the context of the pre-existing equivocal data. The current study confirms that, across the six available RCTs, patients randomized to endovascular therapies have significantly better clinical

Table 5 Outcome results comparing intra-arterial with medical treatment

\begin{tabular}{|c|c|c|c|}
\hline Outcome measure & $\begin{array}{l}\text { Intra-arterial arm } \\
\mathrm{N}(\%) \text {, unweighted }\end{array}$ & $\begin{array}{l}\text { Medical arm } \\
\mathrm{N}(\%) \text {, unweighted }\end{array}$ & OR $(95 \% \mathrm{Cl})$ or $p$ value \\
\hline \multicolumn{4}{|c|}{ Included studies with LVO confirmed at time of randomization (dataset 1) } \\
\hline \multicolumn{4}{|l|}{ Primary outcome: } \\
\hline mRS $0-2$ at 90 days & $251(38.3 \%)$ & $136(25.8 \%)$ & $1.67(1.29$ to 2.16$), p=0.0001$ \\
\hline \multicolumn{4}{|l|}{ Secondary outcomes: } \\
\hline $\mathrm{mRS} 0-1$ at 90 days & $156(23.8 \%)$ & $66(12.5 \%)$ & 1.93 (1.39 to 2.68$), p<0.0001$ \\
\hline $\mathrm{mRS} 0-3$ at 90 days & $348(53.1 \%)$ & $224(42.4 \%)$ & $1.46(1.16$ to 1.85$), p=0.002$ \\
\hline Mortality at 90 days & $122(18.6 \%)$ & $114(21.6 \%)$ & 0.80 (0.60 to 1.07$), p=0.13$ \\
\hline mRS shift analysis & Mean 3.35 & Mean 3.73 & $p<0.0001$ \\
\hline \multicolumn{4}{|c|}{ All included studies (dataset 2) } \\
\hline \multicolumn{4}{|l|}{ Primary outcome: } \\
\hline $\mathrm{mRS} 0-2$ at 90 days & 419 (39.1\%) & $271(32.6 \%)$ & 1.27 (1.04 to 1.54$), p=0.018$ \\
\hline \multicolumn{4}{|l|}{ Secondary outcomes: } \\
\hline mRS $0-1$ at 90 days & $270(25.2 \%)$ & $169(20.3 \%)$ & $1.22(0.97$ to 1.53$), p=0.09$ \\
\hline mRS $0-3$ at 90 days & $600(56.0 \%)$ & $412(49.5 \%)$ & $1.25(1.04$ to 1.51$), p=0.019$ \\
\hline Mortality at 90 days & $203(19.0 \%)$ & $156(18.8 \%)$ & 0.96 (0.76 to 1.22$), p=0.73$ \\
\hline mRS shift analysis & Mean mRS 3.16 & Mean mRS 3.42 & $\mathrm{p}=0.003$ \\
\hline
\end{tabular}

LVO, large vessel occlusion; mRS, modified Rankin Scale score. 
Figure 1 Weighted fixed-effect model showing effect of treatment arm on primary outcome for randomized patients with confirmation of large vessel occlusion.
Outcome: mRS 0-2

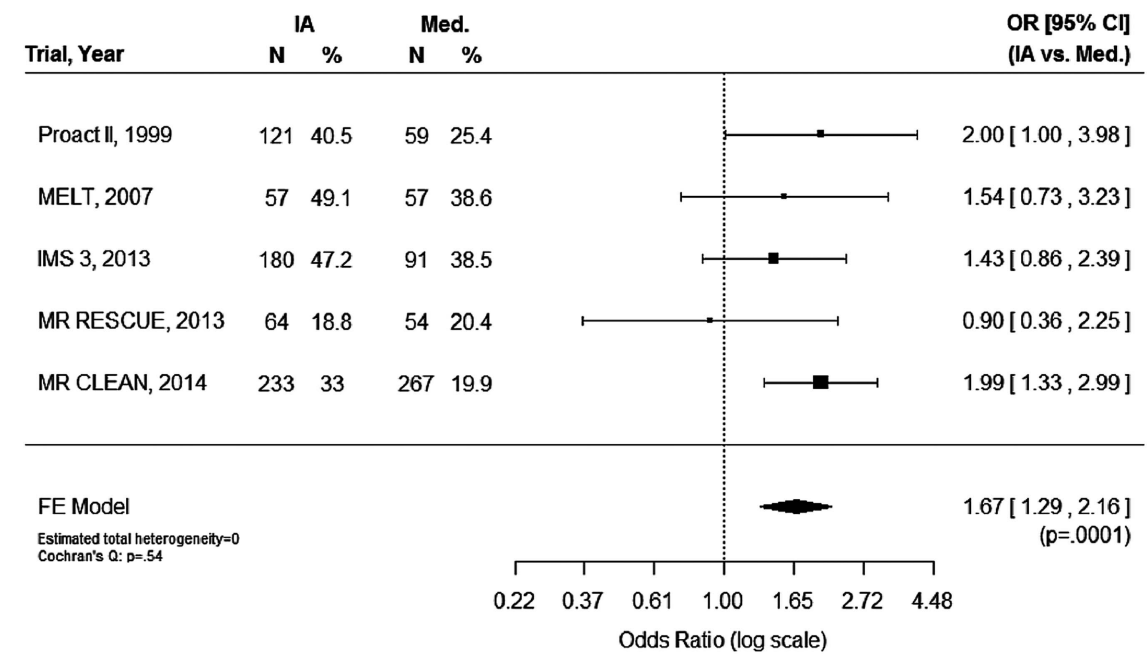

outcomes. This effect is stronger when only those patients with LVO documented on vascular imaging are included. Our analysis thus further underscores the importance of confirming LVO prior to endovascular intervention.

The pre-specified primary outcome measure chosen in this meta-analysis was mRS $0-2$ at 90 days as it is the most commonly used primary outcome in recent stroke literature. In fact, of the six included trials, three used mRS $0-2$ at 90 days as the pre-specified primary outcome measure. However, in those patients with LVO confirmation (dataset 1), all outcome measures demonstrated benefit for endovascular therapy-including mRS $0-1$, mRS $0-3$, and mRS shift analysis.

There are significant limitations to this meta-analysis. Most importantly, the included studies are heterogeneous and are not necessarily comparable. The trials were carried out on different continents, with different enrollment criteria, and used variable medical and endovascular therapies. To address these potential discrepancies, an ANOVA was used to test whether any of the heterogeneity could be explained by study year, location, number of centers, difference in mean NIHSS between the endovascular and medical arms, difference in mean age between endovascular and medical arms, and mean time to endovascular treatment and treatment modality. None of these was associated with clinical outcome. It is likely that the varied trial outcomes are a result of different study designs and revascularization results. These factors are difficult to control for statistically. Additionally, issue can be taken with the combination of studies with varied and heterogenous designs; however, the current analysis underscores the value of recanalization across varied methods in patients with confirmed LVO. Second, a weighted fixed-effect model, in contrast to a random-effects model, was used to quantify the effect of treatment arm on outcome measures. This was partly chosen because there was no significant heterogeneity across the five studies with confirmed LVO. As result, the analysis was constant for dataset 1 (those with confirmed LVO) across both fixed and random-effects models (both were OR $1.67,95 \%$ CI 1.29 to $2.16, \mathrm{p}=0.0001$ ). Given the persistence of significant effect in the random-effects model, the benefit for patients with confirmed LVO appears to be quite generalizable. In contrast, when the all-patient analysis (dataset 2) was evaluated with a random-effects model, it narrowly missed significance (OR $1.30,95 \%$ CI 0.94 to 1.81 ,

Table 6 Modified Rankin Scale (mRS) scores at 90 days for medical and intra-arterial arms of the included trials

\begin{tabular}{|c|c|c|c|c|c|c|c|c|c|}
\hline \multirow[b]{2}{*}{ Study } & \multirow[b]{2}{*}{ Arm } & \multirow[b]{2}{*}{$\mathrm{N}$} & \multicolumn{7}{|c|}{ Modified Rankin Scale score at 90 days } \\
\hline & & & $0(\%)$ & $1(\%)$ & $2(\%)$ & $3(\%)$ & $4(\%)$ & $5(\%)$ & $6(\%)$ \\
\hline PROACT $\|^{10}$ & $\begin{array}{l}\text { IA } \\
\text { Medical }\end{array}$ & $\begin{array}{r}121 \\
59\end{array}$ & $\begin{array}{l}13 \\
12\end{array}$ & $\begin{array}{r}13 \\
5\end{array}$ & $\begin{array}{r}14 \\
8\end{array}$ & $\begin{array}{l}12 \\
22\end{array}$ & $\begin{array}{l}14 \\
19\end{array}$ & $\begin{array}{l}9 \\
7\end{array}$ & $\begin{array}{l}25 \\
27\end{array}$ \\
\hline MELT ${ }^{11}$ & $\begin{array}{l}\text { IA } \\
\text { Medical }\end{array}$ & $\begin{array}{l}57 \\
57\end{array}$ & $\begin{array}{r}16 \\
5\end{array}$ & $\begin{array}{l}26 \\
18\end{array}$ & $\begin{array}{r}7 \\
16\end{array}$ & $\begin{array}{l}11 \\
18\end{array}$ & $\begin{array}{l}19 \\
21\end{array}$ & $\begin{array}{l}16 \\
19\end{array}$ & $\begin{array}{l}5 \\
4\end{array}$ \\
\hline IMS III ${ }^{2 *}$ & $\begin{array}{l}\text { IA } \\
\text { Medical }\end{array}$ & $\begin{array}{l}415 \\
214\end{array}$ & $\begin{array}{r}13 \\
9\end{array}$ & $\begin{array}{l}17 \\
18\end{array}$ & $\begin{array}{l}13 \\
13\end{array}$ & $\begin{array}{l}17 \\
16\end{array}$ & $\begin{array}{l}15 \\
14\end{array}$ & $\begin{array}{l}5 \\
7\end{array}$ & $\begin{array}{l}20 \\
22\end{array}$ \\
\hline SYNTHESIS ${ }^{4 *}$ & $\begin{array}{l}\text { IA } \\
\text { Medical }\end{array}$ & $\begin{array}{l}181 \\
181\end{array}$ & $\begin{array}{l}12 \\
15\end{array}$ & $\begin{array}{l}18 \\
19\end{array}$ & $\begin{array}{l}12 \\
12\end{array}$ & $\begin{array}{l}20 \\
15\end{array}$ & $\begin{array}{l}18 \\
21\end{array}$ & $\begin{array}{l}6 \\
7\end{array}$ & $\begin{array}{l}14 \\
10\end{array}$ \\
\hline MR RESCUE ${ }^{3 *} \dagger$ & $\begin{array}{l}\text { IA arms } \\
\text { Medical arms }\end{array}$ & $\begin{array}{l}64 \\
54\end{array}$ & $\begin{array}{l}3 \\
6\end{array}$ & $\begin{array}{r}11 \\
7\end{array}$ & $\begin{array}{l}5 \\
7\end{array}$ & $\begin{array}{l}16 \\
22\end{array}$ & $\begin{array}{l}23 \\
22\end{array}$ & $\begin{array}{l}23 \\
11\end{array}$ & $\begin{array}{l}19 \\
24\end{array}$ \\
\hline MR CLEAN ${ }^{8}$ & $\begin{array}{l}\text { IA } \\
\text { Medical }\end{array}$ & $\begin{array}{l}233 \\
267\end{array}$ & $\begin{array}{l}3 \\
1\end{array}$ & $\begin{array}{l}9 \\
6\end{array}$ & $\begin{array}{l}21 \\
13\end{array}$ & $\begin{array}{l}18 \\
16\end{array}$ & $\begin{array}{l}22 \\
30\end{array}$ & $\begin{array}{r}6 \\
12\end{array}$ & $\begin{array}{l}21 \\
22\end{array}$ \\
\hline TOTAL† & $\begin{array}{l}\text { IA } \\
\text { Medical }\end{array}$ & $\begin{array}{r}1071 \\
832\end{array}$ & $\begin{array}{r}10 \\
7\end{array}$ & $\begin{array}{l}15 \\
13\end{array}$ & $\begin{array}{l}14 \\
12\end{array}$ & $\begin{array}{l}17 \\
17\end{array}$ & $\begin{array}{l}18 \\
22\end{array}$ & $\begin{array}{r}7 \\
10\end{array}$ & $\begin{array}{l}19 \\
19\end{array}$ \\
\hline
\end{tabular}


Figure 2 Weighted fixed-effect model showing effect of treatment arm on primary outcome for all randomized patients from the six trials.

Outcome: mRS 0-2

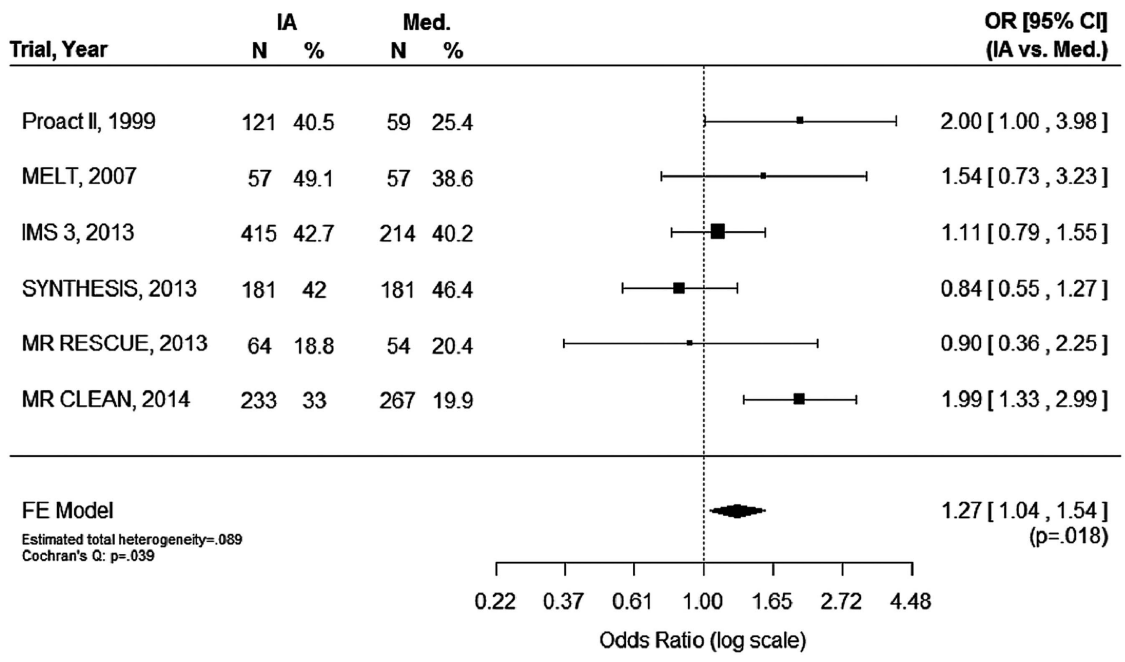

$\mathrm{p}=0.11)$ so the generalizability of the all-patient analysis may be limited. Finally, in instances where subject numbers were extrapolated from percentages, minor errors in subject numbers may have occurred across mRS strata. Any such errors, should they have occurred, would be of limited magnitude and highly unlikely to significantly affect the results of the statistical analysis.

\section{CONCLUSIONS}

This meta-analysis of all prospective RCTs comparing endovascular therapy with medical management in AIS demonstrates superior outcomes in subjects receiving endovascular therapy compared with medical management. This treatment effect was most robust in patients with confirmed LVO. This meta-analysis, in concert with the recent class 1 evidence provided by MR CLEAN, suggests that endovascular therapies produce superior clinical outcomes compared with medical management in patients presenting with AIS from LVO.

Contributors All authors contributed to the manuscript through data acquisition, data analysis, manuscript composition, and/or critical review of the manuscript. All authors provided final approval for publication.

Competing interests DF serves as a consultant and receives royalties from Codman Neurovascular; he serves as a consultant to ev3-Covidien; and he receives research support from Microvention and Siemens Medical Imaging. DJF receives research support and travel expenses from Penumbra. AST serves as a consultant and receives research grants from Stryker, Penumbra, Microvention, Codman, Covidien, and Lazarus Effect. JM serves as a consultant to Medina Medical, Pulsar, Lazarus Effect, and Edge Therapeutics; has investor interests in Blockade Medical and Medina Medical; and is on the Advisory Board for Codman Neurovascular. KMF, DN and MF have no competing interests.

Provenance and peer review Not commissioned; externally peer reviewed.

\section{REFERENCES}

1 [No authors listed]. Tissue plasminogen activator for acute ischemic stroke. The National Institute of Neurological Disorders and Stroke rt-PA Stroke Study Group. N Engl J Med 1995;333:1581-7.

2 Broderick JP, Palesch YY, Demchuk AM, et al. Endovascular therapy after intravenous t-PA versus t-PA alone for stroke. N Engl J Med 2013;368:893-903.

3 Kidwell CS, Jahan R, Gornbein J, et al. A trial of imaging selection and endovascular treatment for ischemic stroke. N Engl J Med 2013;368:914-23.

4 Ciccone A, Valvassori L, Nichelatti $M$, et al. Endovascular treatment for acute ischemic stroke. N Engl J Med 2013;368:904-13.

5 Chimowitz MI. Endovascular treatment for acute ischemic stroke--still unproven. N Engl J Med 2013;368:952-5.

6 Albuquerque FC, Fiorella $D$, Hirsch JA, et al. The tribulations of stroke trials. J Neurointerv Surg 2013;5:181-3.

7 Khalessi AA, Fargen KM, Lavine $S$, et al. Commentary: societal statement on recent acute stroke intervention trials: results and implications. Neurosurgery 2013;73: E375-9.

8 Dippel D, Berkhemer O, Fransen $\mathrm{P}$, et al. Results of the multicenter randomized clinical trial of endovascular treatment for acute ischemic stroke in the Netherlands. 9th World Stroke Conference; 25 October 2014, Istanbul, Turkey.

9 Viechtbauer W. Conducting meta-analyses in R with the Metafor package. J Stat Software 2010:36:1-46

10 Furlan A, Higashida R, Wechsler L, et al. Intra-arterial prourokinase for acute ischemic stroke. The PROACT II study: a randomized controlled trial. Prolyse in Acute Cerebral Thromboembolism. JAMA 1999;282:2003-11.

11 Ogawa A, Mori E, Minematsu K, et al. Randomized trial of intraarterial infusion of urokinase within 6 hours of middle cerebral artery stroke: the middle cerebral artery embolism local fibrinolytic intervention trial (MELT) Japan. Stroke 2007;38:2633-9.

12 Demchuk AM, Goyal M, Yeatts SD, et al. Recanalization and Clinical Outcome of Occlusion Sites at Baseline CT Angiography in the Interventional Management of Stroke III Trial. Radiology 2014;273:202-10.

13 Nogueira RG, Lutsep HL, Gupta R, et al. Trevo versus Merci retrievers for thrombectomy revascularisation of large vessel occlusions in acute ischaemic stroke (TREVO 2): a randomised trial. Lancet 2012;380:1231-40.

14 Saver JL, Jahan R, Levy El, et al. Solitaire flow restoration device versus the Merci Retriever in patients with acute ischaemic stroke (SWIFT): a randomised, parallel-group, non-inferiority trial. Lancet 2012;380:1241-9. 